\title{
Metaphors and the Degree of Conventionality in Translation of Prose Fiction: A Fraction of the Whole in Focus
}

\section{Las metáforas y el grado de convencionalidad en la traducción de la ficción en prosa: Una parte del todo en el punto de mira}

\begin{abstract}
AKBAR HESABI a.hesabi@fgn.ui.ac.ir University of Isfahan

MOBINA BAKHSHI bakhshim636@gmail.com University of Tabriz

POURIA SADRNIA pouria.Sadrnia@yahoo.com

Fecha de recepción: 02/06/2021

University of Isfahan

Fecha de aceptación: 29/09/2021

Abstract: The idea of metaphor classification is regarded as how felicitously they are entrenched in the everyday language spoken by people. Metaphor conventionality can be regarded as a scale whose opposite ends constitute conventional and creative metaphors. Logic indicates that the majority of linguistic metaphors are conventional rather than novel, since an excess of novel metaphors may remarkably bring about "communicative surprise" (Rabadán Alvarez, 1991), thus increasing cognitive processing time. This study seeks to scrutinize the scale of conventionality in the Persian translation of $A$ Fraction of the Whole done by Peyman Khaksar. Based on purposive sampling, some chapters of the novel along with their Persian translations were selected for analysis. MIP known as Metaphor Identification Procedure put forward by the Pragglejaz Group (2007) was employed in the study to identify metaphors. The findings reveal that, sometimes, the metaphors used in L1 are novel or creative, but the translator draws upon conventional or entrenched ones in L2, or vice versa. The aim is to show the translator's choice of metaphor in terms of a conventionality scale using some previous cognitive models in this regard.
\end{abstract}

Key Words: Conceptual metaphor, Conventionality scale, Creativity, Translation, Peyman Khaksar, A Fraction of the Whole. 
Resumen: La idea de clasificación de las metáforas se corresponde con el nivel de arraigo de éstas en el lenguaje del día a día de las personas. La convencionalidad de las metáforas puede considerarse como una balanza cuyos extremos opuestos constituyen metáforas convencionales y creativas. La lógica indica que la mayoría de las metáforas lingüísticas son convencionales y no novedosas, ya que un exceso de metáforas novedosas puede provocar una notable "sorpresa comunicativa» (Rabadán Álvarez, 1991), aumentando así el tiempo de procesamiento cognitivo. La creatividad metafórica, el otro extremo de la balanza de convencionalidad, puede verse como el uso de metáforas conceptuales y/o sus manifestaciones lingüísticas que pueden ser creativas o novedosas. Este estudio examina la escala de convencionalidad en la traducción al persa de Una parte del todo traducido por Peyman Khaksar. Con base en un muestreo intencional, se seleccionaron algunos capítulos de la novela junto con sus traducciones al persa para su análisis. En el estudio se hizo el uso de MIP conocido como procedimiento de identificación metáfora, propuesto por el Grupo Pragglejaz (2007) para identificar las metáforas. Los hallazgos revelan que, a veces, las metáforas utilizadas en L1 son nuevas o creativas, pero el traductor recurre a las convencionales o capacitadas en L2, o viceversa. El objetivo es mostrar la elección de la metáfora por parte del traductor en términos de una escala de convencionalidad utilizando unos modelos respectivos cognitivos previos.

Palabras clave: Metáfora conceptual, Escala de convencionalidad, Creatividad, traducción, Peyman Khaksar, Una parte del todo.

\section{INTRODUCTION}

The mélange and conciliation of Translation Studies (henceforth TS) with Cognitive Linguistics (henceforth $\mathrm{CL}$ ) is embryonic. The advent of $\mathrm{CL}$ in the 1970s with its promising avenues challenged longstanding theories and approaches of TS, among the most prominent of which were the concept of translation and experiential notion of the meaning. Cognitively speaking, translating is no longer deemed as a plain transfer from the Source Language (SL) to the Recipient or Target Language (TL). Instead, having a translator as a language mediator in mind, translation then would be stipulated as a manipulation, a retexualization steered by a mediator who is adept in both languages and is cognizant of what is functionally appropriate in the TL (Ana Rojo and Iraidelbarretxe-Antuñano, 2013, p. 13). CL highlights the notion of experiential meaning viewing meaning as cognitively constructible through human experiences and senses; this approach, consequently, regards TS as a communicative process (Rojo \& IbarretxeAntuñano, 2013, p. 7). CL's significant contribution to the field of TS is 
undeniable; in other words, CL has materially challenged some previously revered theories of meaning and translation, making TS enter a new realm of description and explanation under the shadow of CL (Rojo \& IbarretxeAntuñano, 2013: Schwieter \& Ferreira, 2017). In his Descriptive Translation Study and Beyond, Toury (1995), in retrospect, explores TS socially. He ventures to make a dainty comparison between translation act and translation event (Schäffner and Chilton, 2020). Translation act delineates cognitive aspects of translating (process) whereas translation event refers to the socio-cultural, situational, ideological and historical context embodying the translation act (Toury, 1995). As Schäffner and Chilton (2020) argue, departure from linguistic-based theories to Descriptive Translation Studies (DTS) and Cultural Turn and Cognitive aspects, has made the conception of translation and the pertinent phenomenon thereof anew. Such departure and developments led to the emergence of different outlooks on metaphor and metaphoric expressions. Metaphors, in their classical rhetoric sense, are regarded as an emotive or an ornamental device in literary studies, a persuasive device, and a form of deviation from literal meaning in structural linguistics. Nonetheless, Lakoff and Johnson (1980/2003), with the advent of $\mathrm{CL}$, introduced a novel perspective towards metaphor - Conceptual Metaphor Theory (CMT). Within DTS, two approaches to translation were postulated by Toury, namely descriptive and prescriptive approaches. Shuttleworth and Cowie (1997) argue that prescriptive approaches try to prescribe; in a sense, they are shaping the translation based on extant strategies and prescriptions in a given socio-cultural environment. Rojo \& Ibarretxe-Antuñano (2013) believe that prescriptive approaches are normative and view ST as a model to be imitated with a special focus on mistakes and losses in translation by providing down-to-earth strategies to be applied in the translation act; however, as Schäffner (2004) argues, descriptive approaches highlight "what translations are actually like». The final premises of descriptive approaches are: a) Describing the phenomenon of translation (Munday, 2001, p. 11), b) Locating the ST within the recipient culture to look at its acceptability and significance c) Attempting to reach the universals of translation (Toury, 1995). Despite few sound scholarly studies such as Al-Hasnawi (2007), Dickins (2005), Maalej (2008), Schäffner (2004), and Tirkkonen-Condit (2001), metaphor analysis still suffers from the paucity of cognitive studies.

This study investigates the scale of conventionality in the Persian translation of $A$ Fraction of the Whole, a novel penned by Steve Toltz in 2008. We will argue that sometimes the metaphors used in the source text are novel or creative, but the translator chooses conventional ones in the target text, or vice versa. The objective is to show the translator's choice of metaphor in terms of a conventionality scale. In other words, we want to 
know the translator's disposition in translating novel or conventional metaphors. There are several reasons for our choice of novel metaphors alongside conventional ones: first, lexicalized metaphor has gained more attention on the part of researchers than novel metaphor; the latter still lacks an adequate translational framework. Secondly, our predominant focus is not on the frequency of occurrence, but rather translational choices. In this regard, the pursuit is to provide possible explanations for the translator's choice in terms of this scale. We hope that this paper will lay the foundations for further research.

\section{BACKGROUND OF STUDY}

Through the eyes of Cognitive Linguistics (CL), metaphor refers to a pattern of conceptual association, rather than to an individual metaphoric usage or a linguistic phenomenon. For Dobrovol'skij and Piirainen (2005), metaphors are not related to language; instead, they are a stock of thoughts highlighting one of the rudimentary principles of human cognition. In a similar vein, studying metaphor legitimizes confrontation with hidden facets of cognition and culture (Lakoff and Turner, 1989). Lakoff and Johnson (1980/2003) discuss three main types of metaphor: Ontological, Orientational, and Structural. Ontological metaphors, of which personification is a good example, are the basic ways we use for understanding our experiences. Ontological metaphors, in fact, reflect ways of conceptualizing ideas, emotions, and events as substances and physical objects. Orientational metaphors are defined as the ones involving spatial relationships. These metaphors, like HAPPY IS UP and SAD IS DOWN, give concepts spatial orientations. Structural metaphors are the ones in which the source domain (concrete concept) provides a knowledge structure for the more abstract one (Lakoff and Johnson, 1980/2003). Therefore, the structure of the source domain makes us apprehend the target domain, as in ARGUMENT IS WAR.

In order to scrutinize the translation of metaphors in English scientific texts, Shuttleworth (2011) utilizes a multilingual corpus and concentrates on the two levels at which metaphors have been studied: micro and macro levels. Micro-level can be explained as the translation procedures taken for each metaphorical expression in a text. On the other hand, Macro-level tries to explore the clusters of mapping. Maintaining metaphorical expressions was considered as the usual, the expected procedure across all languages. $\mathrm{He}$ argues that individual metaphorical expression is what is "lost» in the process of translation, not the whole mappings. This scholar further analyzes the translation of scientific metaphors (Shuttleworth, 2017). 
Some other studies have focused their attention on particular types of metaphor in translation. For instance, Safarnejad et al. (2014) have explored the translation of emotion metaphors, such as happiness and sadness, from Persian into English. Nevertheless, their data was not extensive, since it was simply comprised of a Persian novel and two of its English translations. They applied the MIP procedure to identify the metaphors. This procedure is a reliable one for identifying metaphorical words in discourse (see Steen, 2017 for more information on MIP and its expanded version MIPVU). Their predominant focus was on emotion metaphors, both linguistic and conceptual. This comparative study aimed to show the different cognitive mappings in these two cultures. In fact, they demonstrated different ways of conceptualization in Persian and English. They categorize their strategies of translation as a) translating linguistic metaphors in SL into equivalent metaphorical expressions in TL; b) translating metaphors in SL into nonmetaphorical expressions in TL; c) mistranslation and d) literal translation (Safarnejad et al., 2014, p. 110).

Conceptual metaphors of time were comparatively analyzed in two languages of Persian and English in a study conducted by Ghorbanpour et al. (2019). They categorized various metaphorical expressions of time into the relevant underlying conceptual metaphors. The findings revealed that English and Persian manifest very similar cognitive mappings. Save some minor differences, the two languages used similar metaphors to comprehend time as an abstract concept.

Andreas Musolff (2020) studied the metaphors used by world Englishes to conceptualize national identity. This research aimed to show the great variation in understanding nation in terms of a body by speakers of international English. The findings manifested five main metaphors: nation as a body, nation's territory as a body, nation as a body part, nation as part of ego, and nation as a person.

Abdulhameed (2019) conducted a translation study on scientific metaphors, claiming that, in comparison with literary metaphors, scientific metaphors have been overlooked. Therefore, this study's objective was to identify the strategies that the translators use when confronted with scientific metaphors. Results revealed that literal and explication strategies were the most and the least frequently used strategies respectively.

Regarding anthropomorphous metaphors, Burmakova and Marugina (2014) explored the conceptual mapping between NATURE and MAN. Their study was a contrastive analysis of Russian short stories with their English translations. As their theoretical background, they employed Mandelblit's (1995) cognitive translation hypothesis. Based on the model, two scenarios 
exist in metaphor translation. Similar mapping condition (SMC) bears no conceptual shift from the source to the target language, whereas in different mapping condition (DMC), a conceptual shift takes place from the source to the target language. Their result showed that, in translating anthropomorphous metaphor, the source domain and anthropocentric perspective were preserved in the target language. Based on their result, the most applicable strategy for translating metaphors in the condition of SMC was reproducing the same image of the SL in the TL.

Another study carried out by Yan et al. (2010) explores how crosscultural variations in conceptual metaphors exert influence upon rendering of such metaphors. They further wanted to know how these renderings highlight the conceptual metaphors. To fulfill the study, they analyzed the FEAR metaphors rendered from English to Chinese. The findings showed that, even though the metaphors were shared by the SL and the TL, SL metaphors (English metaphorical expressions) were not necessarily translated as the same metaphorical expressions in the TL (Chinese). In another finding, what this study adds is that conceptual shifts do not merely take place in the case of DMC proposed by Mandelblit (1995).

Omar, Lamis (2012) investigated the translatability of creative metaphors in several Arabic translations of Shakespeare's Othello and Macbeth, applying the perspective of CMT (Conceptual Metaphor Theory). The findings revealed that, in spite of the fact that metaphorical conceptualization has a structure universally shared, not all metaphors are possible to be translated in one way. This idea rejects the superiority of metaphor universality, emphasizing the factors of intentionality and creativity.

Several erudite studies were only based on product analysis; precisely speaking, with the rapid pace of technological developments, translation studies depart from product-oriented perspectives to the process-oriented ones. Such departure is a praiseworthy means for uncovering different aspects of translation, metaphor and cognition (Schäffner \& Shuttleworth, 2013). The degree of lexicalization plays a crucial role in determining various types of metaphors. For Van den Broeck (1981), metaphors are conventional, lexicalized, and private. Dagut (1976) classifies metaphors as ephemeral and established. Dickins (2005) simplified them as lexicalized and non-lexicalized. Dobrzyńska (1995) categorizes metaphors as dead and live metaphors. Drawing on the previous categorization, however, in the present article we wish to analyze metaphors based on the conventional and creative dichotomy. One of these classifications is according to the conventionality of metaphor. The word "conventional» is used in the sense of entrenched, and this issue concerns conceptual metaphors and their 
corresponding linguistic realizations. For instance, the majority of speakers would not even recognize that they use metaphorical language when they use the word construct in the context of theories. Thus, we can say that such metaphorical expressions are extremely conventionalized; that is to say, they are well entrenched or even cliché.

Highly unconventional or novel metaphors are found at the opposite end of this scale. Kovecses (2010) gives an example of two linguistic metaphors that realize the same conceptual metaphor. One of these examples originates from Robert Frost's poem «The Road Not Taken.» Kovecses aims to show that Frost uses the conventional LIFE IS A JOURNEY metaphor in creative ways. However, it is important to know that novel metaphorical expressions do not exclusively belong to the realms of arts and literature. Many creative speakers can come up with novel linguistic metaphors which manifest conventional conceptual metaphors. Studies reveal that it is not just as simple to find unconventional conceptual metaphors for an abstract concept. However, some people do use lessconventional ways of conceptualizing things and experiences. For example, Lakoff and Johnson mention one such novel conceptual metaphor: LOVE IS A COLLABORATIVE WORK OF ART (Kovecses, 2010). This metaphor emphasizes one aspect of love which conventional metaphors do not, and it is the more action-oriented aspect of it.

Entrenched linguistic metaphors are conventionalized because their metaphorical extensions (contextual senses) are included in standard contemporary language dictionaries, whereas the lexical items whose contextual meanings are not thus codified have been classified as novel metaphors (Muller, 2008). Since a considerable number of novel metaphors may increase processing time and even hinder comprehension, the vast majority of linguistic metaphors are conventional rather than novel. Based on the traditional view, the prototypical metaphor is vivid and creative. Metaphor and creativity would therefore appear to be closely connected and inseparable. However, elaborating on Lakoff's cognitive approach, much recent research has concentrated on showing how language is pervaded by conventional metaphor, and cross-linguistically so.

When poets and writers create new metaphors, they often tend to be noteworthy because of their strange character. Lakoff and Turner (1989) made two important points regarding conceptual metaphors in literature. First, they demonstrated that poets and writers make heavy use of conventional metaphors. The reason for this is that the conceptual metaphors are based on shared bodily experiences - for both non-poets and poets. Second, they argued that poets utilize four common conceptual devices so as to create novel metaphors out of the shared materials of 
everyday thought and language. These devices are as follows: extending, elaboration, questioning, and combining. For instance, the conventional metaphor LIFE IS A JOURNEY is expressed in a novel way in Dante's Divine Comedy: «In the middle of life's road, I found myself in a dark wood". Here, the novelty stems from the fact that the autor has extended the conventional metaphor LIFE IS A JOURNEY by adding a new aspect (the presence of a dark wood) to the source domain. Although these four cognitive strategies also exist in more ordinary forms of language use, such characterization of poetic metaphor creativity emphasizes another possible standard of metaphorical creativity, besides novelty. One suggested defining characteristic of creativity, in general, is the awareness of the creator (Nacey, 2013). Therefore, creative metaphoricity requires deliberateness: metaphors created for a specific goal.

\section{THEORETICAL FRAMEWORK}

Many efforts have been put into the translation of metaphor in translation studies. Several approaches have been proposed to this end: descriptive, prescriptive, and cognitive, and various types of discourse were taken into consideration. In other words, three points are discussed in translating metaphors: transfer procedures, different text types, and cultural variation (Burmakova, 2014). Traditionally being considered as a merely linguistic phenomenon, metaphor was looked at as an aesthetic figure of speech whose translation was based on its components (i.e. vehicle, tenor) and types. However, it is the cognitive approach to metaphor which has very recently been applied to translation studies. It can be argued that the originality or conventionality of conceptual metaphors is one of the features that characterizes this cognitive approach to metaphor translation.

The criterion of time is taken into account in Newmark's metaphor typology. According to his prescriptive model of metaphor translation, the most translatable metaphors are dead ones, while the translatability of stock and original ones is proportioned to the proximity of the two systems involved (Newmark, 1988). Newmark argues that original or novel metaphors depict the writer's comments on life and their personality; this means that they should be illustrated intact in translation. Intactness, in this regard, means that the metaphor should be translated in a literal form regardless of its nature such as cultural, universal, or obscurely subjective (1988, p. 112). However, he explains that it is possible to reduce the image of this kind of metaphor to its sense if an original cultural metaphor is ambiguous and not of great importance.

Van den Broeck's (1981) descriptive model suggests some alternative approaches which are based upon the traditional understanding of 
metaphor. Mandelblit (1995) proposes the Cognitive Translation Hypothesis consisting of two patterns for the translation of metaphors: 1. Similar mapping conditions (in case there is no conceptual change between the SL and TL metaphors); 2. Different mapping conditions (if a conceptual change occurs). Kovecses (2005) adds two schemes to Mandelblit's Cognitive Translation Hypothesis and elaborates on it:

- Metaphors of similar mapping conditions and similar lexical implementation

- Metaphors of similar mapping conditions but different lexical implementation

- Metaphors of different mapping conditions but similar lexical implementation

- Metaphors of different mapping conditions and different lexical implementation

Taking the variable of «use» (Steen, 1994 and Indurkhya, 1992) into account, metaphors can be classified into three groups: 1) novel metaphors dependent upon an already existing similarity, consisting in a new mapping or an unusual combination of cognitive domains; 2 ) «pure» novel metaphors dependent upon a created similarity; 3) combination of literal and metaphorical senses (Le Guern, 1976). According to Van den Broeck (1981, p. 84), "private» metaphors in literary discourse are more easily translated than conventional ones because they are less culturally bound.

In his cognitive stylistic approach to metaphor translation, Hasan Said Ghazala (2012) shows how original metaphors, especially in political and literary discourse, are translated from English into Arabic. He gives us two examples of literary metaphors: one narrative, another poetic. The first example is a metaphorical narrative passage by Winterson, which centers on the target domain MISERY. Hasan Said Ghazala argues that the translation is as novel and original as the source text due to the great significance of the style of literary texts, and to the universality of metaphors. Being mostly universal, the source domains are constructed in the Arabic translation in the same way, although there are some exceptions (see the text in Simpson, 2004, pp. 42-43). He compares this version with another creative version of translation which constructs new source domains that differ in the type of conceptualization. Interestingly enough, he concludes that it is possible in such texts for translators to construct new metaphorical domains for the same concept. The attempt to construct the same mental images in the target text is due to the universality of these creative metaphors, «in which case the translator may optionally ignore the cultural factor, however temporarily» (2012, p. 66). 


\section{NOVEL METAPHOR}

The term «novel» (Cristofoli, Dyrberg, and Stage, 1998; Rabadán Álvarez, 1991) has been preferred over other choices because of its transparency. The most defining characteristic of novel metaphors is that they «flout addressee expectations» (Rabadán Álvarez, 1991, p. 142).

Novel metaphorical expressions possess these attributes: a) such metaphors are not standardized and thus not commonly used; b) they may have various linguistic forms, and there is no restriction on the length of such metaphors; c) they can be classified as several groups (Steen 1994; Indurkhya 1992): pure novel metaphors; novel metaphors (dependent upon conventional underlying conceptual metaphors) manifesting surprising combinations of words, and novel metaphors possessing an original meaning even if the linguistic forms lack originality. Novel metaphors have been the focus of some metaphor translation studies, such as Eva Samaniego Fernández's (2013) research on novel metaphors in EnglishSpanish newspaper translation.

We have several reasons for our selection of novel metaphors alongside conventional ones: first, lexicalized or standardized metaphor has gained more attention on the part of researchers than novel metaphors; the latter does not possess an adequate translational framework yet. Secondly, our aim is not to focus on the frequency of occurrence, but on the translator's choices. In this regard, the pursuit is to provide possible explanations for the translator's choice in terms of the scale of conventionality.

\section{Methodology}

\subsection{Materials}

Our data consists of a novel by Steve Toltz, namely A Fraction of the Whole, and its Persian translation. A Fraction of the Whole, published in 2008 by Spiegel \& Grau, is a comic novel recording the tale of a family of Australian outcasts. This funny masterpiece has constantly been compared to A Confederacy of Dunces by John Kennedy Toole, and it was shortlisted for the Man Booker Prize and the Guardian First Book Award. Steve Toltz's debut novel abounds in creative metaphors and poses a challenge to its translator. It provides us with an adequate number of conventional and novel metaphors, and reveals some difficulties certain to arise when translating metaphors. Various Persian translations of this book are available, but a translation by Peyman Khaksar published by Cheshmeh Publications in 2014 is the most widely-read and thus the best one. The present study has drawn on this translation. Based on purposive sampling, we selected those parts of the novel that were particularly useful for our study. 


\subsection{Procedure}

The identification of metaphors is done based on MIP (Metaphor Identification Procedure) (Pragglejaz Group, 2007), an explicit method to find words metaphorically used in texts. First, we read the entire text-discourse to establish a general understanding of the meaning. Then we determine the lexical units in it: for each lexical unit in the text, we establish its meaning in context and determine if it has a more basic contemporary meaning in other contexts. For our purpose, basic meanings tend to be: a) more concrete; b) related to bodily actions; $c$ ) more precise; d) historically older. If the lexical unit has a more basic current-contemporary meaning in other contexts than the given text, we decide whether the contextual meaning contrasts with the basic meaning but can be understood in comparison with it; if yes, we mark the lexical unit as metaphorical. Based on our previous reading of the whole novel, we selected only some of the chapters and parts which were teeming with metaphors, especially creative ones. Needless to say, both English and Persian metaphors have been identified using this procedure.

After metaphor identification, we determine their positions on the scale of conventionality; i.e. whether the metaphors are relatively or absolutely novel. This is a rather difficult job given that in literary discourse there is a great deal of creative metaphors; therefore, one cannot pinpoint their positions on the scale. We try to address this problem by considering two important points: 1 . Sometimes, the author has the conventional conceptual metaphor in mind but uses unconventionalized linguistic expressions that make it manifest. 2. By comparing the novel metaphors under investigation with those of other narrative literary texts in order to see if they have been already used (it is obvious that this comparison can be made on only a small scale). When the question of novelty or conventionality of English metaphors is settled, we compare the chosen English metaphors with their Persian translations to see how they vary in terms of the conventionality scale.

The present study is primarily based on cognitive models of metaphor translation put forward by Mandelblit (1995), Kovecses (2005), and AlHasnawi (2007). Considering these main approaches and the patterns/possibilities of metaphor translation (Kovecses, 2014), we discuss the translator's choice of Persian equivalents in terms of a conventionality scale.

\section{RESULTS AND DISCUSSION}

Below are examples of conventionalized and creative metaphorical expressions found in A Fraction of the Whole, along with their underlying conceptual metaphors and Persian translations. 


\subsection{Creative Metaphors}

- Flirting with life but too shy to go all the way. (LIFE IS AN ATTRACTIVE MAN/WOMAN)

$$
\text { با زنديى بازى ميكرديم ولى خجالنى تر از آن بوديم كه تا ته ماجر ا برويم. }
$$

- I feel $\boldsymbol{d} w a r f e d$ by our lives. (LIFE IS SOMETHING EXTREMELY LARGE)

$$
\text { در مقابل زندگى هامان احساس كوتولنى ميكن. }
$$

- Then Dad got distracted with the time-chewing business of staring into space. (TIME IS FOOD)

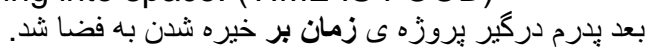

- These are just some of the vegetables with which we make a Jasper broth. (PERSONALITY/IDENTITY IS A SOUP/BROTH) (THE THINGS THAT MAKE YOUR IDENTITY ARE VEGETABLES OF THE SOUP)

$$
\text { اين ها تازه جند نا از سبزى هايیى هستن كه باهاشون سوبٍ جسبر رو درست ميكنيم. }
$$

- This is mankind fresh out of the box! (MANKIND IS AN EQUIPMENT)

$$
\text { آدميز اد به صورت بيش فرض همين است. }
$$

- I imagine her smashing through the confines of her cemented ideas with all those brutal, beautiful truths. (IDEAS ARE BUILDINGS) ميكربند

$$
\text { تصورش ميكنم كـه آن حقايق خشونت بـار و زيبـا جـارجوب محكم عقايش راخري }
$$

I saw all the love triangles and few love rectangles and one crazy love hexagon in the back room of a sweaty Parisian café. (LOVE RELATIONSHIP BETWEEN THREE PEOPLE IS A TRIANGLE)

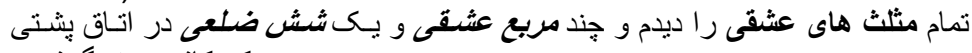

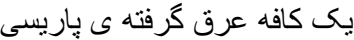

- I guess one man's burning bush is another man's spot fire. (IMPORTANCE IS A FIRE)

$$
\text { فكر كنم جيزى كه براى يكى نفر بوته شى شعله ور است براى كسى ديكر آتش خردى }
$$

- As you know, I never fit in; I couldn't even squeeze in. (SOCIAL INTERACTION IS CONTAINMENT IN A PRESCRIBED SHAPE)

$$
\text { نميتو انستم خود را در كروهى جا كنم، حتى به زور. }
$$

- She had been practicing dying for a lot longer than me. It was going to be a race to the finish line! (DEATH ISA RACE)

$$
\text { او مدت ها قبل از من تعرين مردن را آغاز كرده بود. براى خط بايسان رقابت سختي }
$$

She wasn't just at death's door; she was pounding on it! (DEATH IS AN ENTRY) 
او تنها در آستانه ى مرگ نبود. داشت با مشت به در ميكوبيا.

- He'd had a lot bottled up. The stopper was out. (EMOTIONS ARE LIQUIDS WITHIN A BODY-CONTAINER)

خيلى به درون ريخته بود. اكنون احساساتش را تظليه ميكرد.

- How to choose between those memories panting to be told? (Personification, ontological metaphor)

$$
\text { جطور ميشود بين خاطراتى كه نفس نفس ميزنتد تا بازكو شوند، انتخاب كرد؟ }
$$

- Why should I chain myself to the wheel when the wheel itself might be a construct, an invention, a common dream to enslave us? (COMMON BELIEF IS A WHEEL)

جֶر ا بايد در قيد و بند اعتقادات جارى باشم، در حاليكه اين عقايد خود سـاخته ى بشـر

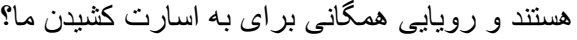

- Life is a brief flicker between two immense voids to which humanity is unfairly conducted. (LIFE IS AN UNSTEADY LIGHT) محكوم شده.

$$
\text { زندكى يــ جشـك كوتـاهى اسـت بين دو خـلا بـى كران كـه انسـان ناعادلانـه بهش }
$$

We painted on a broader canvas than we deserved. (THE WORLD IS A CANVAS)

$$
\text { روى بومى عريض تر از لياقت مان نقاشسى شده بوديه. }
$$

\subsection{Conventional Metaphors}

- $\quad[. .$.$] as if he wanted a trip down memory lane. (MEMORY IS A$ PATH) (REMEMBERING SOMETHING NOSTALGICALLY IS A TRIP DOWN THIS PATH)

$$
\text { انغار خواسته بود سفرى با قطار خاطرات كند. }
$$

- The organization is in ruins. (ORGANIZATIONS/COMPANIES ARE BUILDINGS)

$$
\text { سازمان ويران شده. }
$$

- You and me, we're in the same boat. (PEOPLE WITH A

COMMON FATE ARE PEOPLE IN A SINGLE BOAT)

$$
\text { من و تو سرنشين يه كثنى هنتيم. }
$$

- l'd be on the edge of $m y$ seat. (EMOTIONAL STABILITY IS MAINTAINING POSITION)

$$
\text { سرإياكوش ميشوم. }
$$

- $\quad[. .$.$] , and they gave me four hundred cold shoulders. (DISLIKE IS$ COLDNESS)

جهارصد جشم به سردى نكاهم ميكردند.

- Freedom leaves me cold. (LACK OF INTEREST IS COLDNESS) آز ادى مرا تكان نمبيا هل.

- Bruno seethed at my wide-eyed reverence for books. (ANGER IS A HOT FLUID IN A CONTAINER)

$$
\text { برونو از احتر ام معصومانه من به كتاب جوش مى آورد. }
$$


- I chose a life apart from the common flow. (FLOW OF EVENTS IS FLOW OF WATER)

$$
\text { من خود را از كثتى مادر جدا كرده بودم. }
$$

- It would shake the foundations of common folk. (LIFE IS A BUILDING)

$$
\text { بنيان زندكى مردم عادى رو به لرزه درمياره. }
$$

- It's all downhill from there. (EASY ACTION IS EASY MOTION)

$$
\text { از اون لحظه به بعد ديگه مثل آب خوردنه. }
$$

According to our findings, it can be noted that the translation of creative metaphors is novel and original in most cases. The metaphorical understanding of life and death is prevalent in ordinary language as well as in literature. In this text, life is conceptualized as an attractive man/woman. Moreover, it is metaphorically something extremely large as well as an unsteady light. While the first two metaphors are absolutely creative, the third one is relatively new. The conceptual metaphor LIFE IS AN UNSTEADY LIGHT has already been used in some literary works such as Shakespeare's Macbeth (see Act 5, Scene 5) and David Wong's John Dies at the End (2007). Two of the best examples of creative death metaphors in the text are: DEATH IS A RACE and DYING IS A SPORT. All these new source domains as manifested by the linguistic expressions flirting with life, dwarfed by our lives, life is a brief flicker, a race to the finish line, and practicing dying, are constructed in the Persian translation in a similar way.

There are three more creative conceptual metaphors: PERSONALITY/IDENTITY IS A SOUP, IMPORTANCE IS A FIRE, and THE WORLD IS A CANVAS. We have some evidence which show the third metaphor is relatively novel and creative. The world has already been conceived of as a canvas by Henry David Thoreau in the expression the world is but a canvas to our imagination (see $A$ Week on the Concord and Merrimack Rivers, 1849). The metaphorical linguistic expressions Jasper broth, one man's burning bush is another man's spot fire, and we painted on a broader canvas than we deserved, which manifest the aforementioned conceptual metaphors, are translated in the same way in order to preserve the source domains and metaphorical concepts.

«We can conceive of personification as a form of ontological metaphor» (Kovecses, 2010, p. 39). Ontological metaphors give our vague experiences a basic status in terms of containers, substances, and objects. Personification or anthropomorphous metaphor is also regarded as a creative one, so it pertains to the novel conceptual metaphor category. One example of such a metaphor in the text can be seen in this expression: How to choose between those memories panting to be told? Since personification 
is a kind of creative metaphor, its translation seems as original as the source text.

Interestingly enough, some creative versions of translation may construct new source domains which differ in the type of conceptualization. According to our gathered data, such translations occur much less frequently. The metaphorical expression This is mankind fresh out of the box is translated as ' آدميز اد به صورت بيش فرض همينه '. The source domain has changed from EQUIPMENT to COMPUTER. While the source text conceptualizes MANKIND as a piece of equipment that has been purchased and just opened, the target translation uses the metaphor of a device that is configured to the default settings. Here, it can be argued that the conceptual metaphors are different, but the figurative meanings are the same.

It is crucial to know that some creative metaphors are just linguistically novel. In such cases, the underlying conceptual metaphors remain conventional, but the linguistic expressions have not been conventionalized for the speakers. For instance, as linguistic metaphors, love rectangle and love hexagon may strike us as being novel because the existing element of the source is elaborated on surprisingly. The metaphor that links the concept of a triangle to the concept of a love relationship between three people is so natural. Elaboration captures a pre-existing element of the source domain in an unconventional way (Kovecses, 2010). As a result, love rectangle and love hexagon become creative linguistic metaphors. Such reworking of ordinary metaphors can be seen in another expression: she wasn't just at death's door; she was pounding on it! The conventional conceptual metaphor that this expression realizes is DEATH IS AN ENTRY. Here, the feature of novelty originates from the unusual element that someone can pound on death's door. Toltz extends the metaphor by attaching this facet to it. Once again, the Persian translation of these two examples attempts to preserve the linguistic novelty. In Persian as well as in English, the expressions ' متلث عشقى ' در آستانه ى 'and ' are conventionalized, whereas the others are not.

Sometimes, the metaphors used in English are novel and original, but the translator decides to use conventional metaphors in Persian. This may not happen very often, but this study shows that it is possible. In fact, it is this aspect of our work which is considered to be pioneering. For instance, the creative conceptual metaphor TIME IS FOOD feeding into the linguistic expression time-chewing is changed into the conventional conceptual metaphor TIME IS A RESOURCE in the target text; therefore, time-chewing has been translated as 'زمان بر '. Some of the expressions which realize this

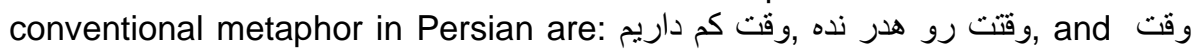


تموم شد. These expressions are similar to the ones representing TIME IS MONEY conceptual metaphor.

Another example of a creative conceptual metaphor changed into a conventional one can be found in this sentence: Why should I chain myself to the wheel when the wheel itself might be a construct, an invention, a common dream to enslave us? Here, the novel conceptual metaphor COMMON BELIEF IS A WHEEL is translated into three Persian conventional metaphors COMMON BELIEF IS A FLUID, BELIEFS ARE STRUCTURES, and CONSTRAINED THOUGHT IS CONSTRAINED

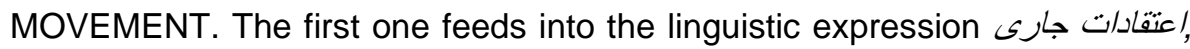
the second into عقايد ساخته ى بشر, and the third into در قيد و بند /عتقادات. While the first conceptual metaphor is conventional only in Persian, the other two are conventional in both Persian and English. The same figurative meaning of the source text is better conveyed in Persian through these conventional metaphors.

We also came across creative linguistic metaphors changed into conventional ones in translation. For instance, smashing through the confines of cemented ideas is a novel expression with an ordinary conceptual metaphor IDEAS ARE BUILDINGS. The translator draws upon a conventional expression in Persian to make manifest the same conceptual metaphor; ' جارجوب محكم عقايد 'is a natural way of talking about ideas in Persian. There are two more examples of such a translation. Squeeze in is a creative linguistic metaphor whose underlying conceptual metaphor, namely SOCIAL INTERACTION IS CONTAINMENT IN A PRESCRIBED SHAPE remains conventional. While the expression «squeeze in" intended in a metaphorical sense may seem strange in English, the Persian equivalents '

' and ' 'به زور خود را جا كردن ' are natural and conventionalized in the context of groups and social interaction.

The last example is an interesting one: He'd had a lot bottled up. The stopper was out. The conventional conceptual metaphor feeding into this expression is EMOTIONS ARE LIQUIDS WITHIN A BODY-CONTAINER; therefore, "the stopper was out» is a novel expression with a conventional conceptual metaphor. If we conceive of the human body as a container for emotion-liquids, then this container should have a stopper. When the stopper is out, emotion-liquids pour out of this container. But this is an unusual reworking of the same ordinary metaphor. Bottle up, which is a conventionalized expression, is rendered into Persian as 'به درون ريخت '. The Persian equivalent is also conventionalized for the speakers. However, «the stopper was out» is a creative linguistic metaphor which is translated as ' احساساتش را تخليه ميكرد 
outburst of emotions. Nevertheless, the type of metaphors with regard to the scale of conventionality differs. While the $L 1$ metaphorical expression is quite original, the L2 metaphor is natural and conventionalized.

Conventional metaphors can also be changed into novel ones in translation, but it very rarely happens. The reason is that conventional metaphors are mostly universal and so pervasive in the mind as well as in the language that it is difficult to change them. We came across a few examples of such a translation in our data, but as with creative metaphors, we will first explain the usual cases, then go through the unusual ones.

The first example is the simplest one: The organization is in ruins. This is a conventional metaphorical expression whose underlying conceptual metaphor is ORGANIZATIONS/COMPANIES ARE BUILDINGS. This وير ان شدن ' conventional conceptual metaphor feeds into expressions such as ', نخريب شدن in Persian. It is highly unlikely that a translator will defy the expectation and render such a familiar metaphor into a novel one in Persian. In fact, it might be difficult for the majority of us to think of organizations in other terms than the BUILDING conceptual metaphor.

It is noteworthy that most conceptual metaphors are based on metonymies. The expression l'd be on the edge of my seat is translated into Persian as ' سر اياخوش ميشوم '. The conceptual metaphor of the source text is EMOTIONAL STABILITY IS MAINTAINING POSITION, but the Persian translator draws upon the conceptual metonymy EARS FOR HEARING ABILITY. The metaphorical expression to be on the edge of one's seat and the Persian metonymic expression ' سر اياكوش شدن ' have the same figurative meaning: to listen attentively to something because you are eager to hear more. What is important for us is that a conventional metaphor is translated into a conventional metonymy; therefore, the Persian expression is as natural as the English one.

It is quite ordinary to speak of emotions in terms of temperature. Kovecses (2003) discusses the concept of emotion in detail. DISLIKE IS COLDNESS and the opposite metaphor AFFECTION IS WARMTH are conventional in English as well as in Persian. In fact, as discussed in the theory of "primary metaphors» (Lakoff, 1999), the correlation between emotion and body heat is universal. As a result, the expression they gave me four hundred cold shoulders is translated as ' جهارصد جشم به سردى نحاهم "To give someone a cold shoulder» can be translated into Persian as ' برد سردى رفتار كردن ' or ' برخورد كردن با كسى ', but because the context is about two hundred students giving four hundred cold shoulders, the translator's choice is quite appropriate. To give someone a cold look» (به 
has the same conceptual metaphor and the same figurative meaning as «to give someone a cold shoulder».

Another instance of emotion metaphor can be seen in the expression freedom leaves me cold. Similar to the previous example, the conventional conceptual metaphor feeding into this expression is LACK OF INTEREST IS COLDNESS. Once again, the translator uses a conventional metaphor in the Persian text and renders the expression as ' آزادى مر ا تكان نميدهد '. While the translation is as conventional as the original text, the conceptual metaphors they realize are different. LACK OF INTEREST IS COLDNESS is changed into EMOTION IS PHYSICAL AGITATION in the process of translation. Furthermore, ANGER IS A HOT FLUID IN A CONTAINER is a universal metaphor. The expression seethe at is just one of its manifestations, which is translated as ' جوش آوردن '-a conventional Persian equivalent. The reason why we view this equivalent as conventional is that it is a well-worn Persian idiom meaning 'to get angry'.

Different facets of events serve as the target domain of the Event Structure metaphor (Kovecses, 2010). EASY ACTION IS EASY MOTION is one of the sub-mappings within this metaphorical system which feeds into the linguistic expression It's all downhill from there. This is translated into Persian as ' از اون لحظه به بعد ديكه مثل آب خوردنه ', an expression which makes manifest the conceptual metaphor EASY ACTION IS EASY SWALLOWING. Easy action is conceived of as easy swallowing in Persian; therefore, the conceptual metaphors differ but the figurative meanings are the same. More importantly, both English and Persian metaphors are equally conventional.

There are three unusual cases in which a conventional metaphor has been rendered into a novel one in Persian. A trip down memory lane is a conventional expression realizing the conceptual metaphor MEMORY IS A PATH and its entailment REMEMBERING SOMETHING NOSTALGICALLY IS A TRIP DOWN THIS PATH. The Persian translator instead of using

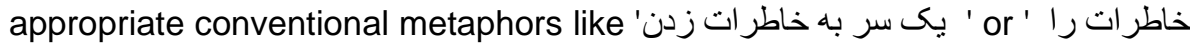
'-each having the conceptual metaphors MEMORY IS AN OLD PLACE TO VISIT and MEMORY IS A BOOK, respectively-chooses to use the novel metaphor MEMORY IS A TRAIN and its entailment REMEMBERING SOMETHING NOSTALGICALLY IS A JOURNEY ON A TRAIN. Therefore, the Persian expression ' سفرى با قطار خاطرات كردن ' is unique and creative, whereas the English text is quite conventionalized. Another example of such a translation is found in the familiar metaphorical expression to be in the same boat. While most translators would think of ' ' as the best Persian equivalent, the version of translation under investigation constructs the same source domain by rendering the English 
expression literally and thus creates a novel metaphor in Persian. The target translation ' سرنشين يك كشتى بودن ' is a novel expression realizing the same English conceptual metaphor PEOPLE WITH A COMMON FATE ARE PEOPLE IN A SINGLE BOAT. A possible explanation for such a translational choice is that the closest Persian equivalent for the metaphorical expression to be in the same boat is a non-metaphor! ' ه 'بودن', though it is a natural and well-worn Persian expression conveying the same sense, does not carry metaphorical value. Therefore, the translator renders the English metaphor literally, giving rise to a novel metaphorical expression in Persian.

Finally, the familiar metaphor FLOW OF EVENTS IS FLOW OF WATER, which is manifested by the expression the common flow, is changed into the creative metaphor COMMON FLOW OF EVENTS IS A خود را از كشنى مادر جدا كردن ' ' is an absolutely original expression which preserves the same figurative meaning of the English text. Arguably, the rationale behind choosing such a violently novel Persian expression for so conventional a metaohor is that the mega-metaphors in that context, being about ships and sea journeys, advocate such a creative translation. In fact, the translator has drawn upon the same source domain used in the megametaphors of that context in order to make the Persian text seem metaphorically homogeneous. This translational choice, which seldom occurs, will not distort the writer's style, provided that it is carefully made.

\section{CONCLUSION}

To sum up, within literary works, the metaphors used by the novelists can be either conventional or creative. Strictly speaking, the scale of conventionality is not merely composed of two opposite extremes, rather this is a continuum on which metaphors with different degrees of conventionality are placed. On the one hand, there are non-lexicalized metaphors which are absolutely or relatively novel, while on the other hand, there is a whole world of lexicalized metaphors which are already established in the language.

In the light of previous background research and all our findings, we can reach the conclusion that metaphor translation is a conceptual mapping from one language to another. As to the novel metaphors, it is widely accepted that they have to be translated literally, except in some obscure or insignificant cases, because novel metaphors demonstrate the writer's creative style and use of language, especially in literary texts. This study, however, argues that: 1 . it is possible for translators to construct new source domains for the same creative metaphors so that the target translation will appear as unique and creative as the source text (the figurative meanings 
obviously remain the same). However, this very seldom occurs. According to our findings, only one example can be thus accounted for (this is mankind fresh out of the box, see above) 2. more importantly, it is possible in some cases to draw upon conventional metaphors in the translation of novel ones. The latter may not happen very often, though. Since such a translational choice departs from what is usually considered to be normal, there should be some justifiable rationale behind it. Sometimes, meaning is better conveyed in the target language by using a more conventional metaphor rather than constructing the same source domain, especially if the novel metaphor used by the writer is ambiguous, difficult to understand, or so strange that the reader of the target text cannot easily communicate with it. In such cases, the translator uses a conventional metaphor while trying to preserve the figurative meaning. Since creative metaphors can be either conceptually or linguistically novel, we can conclude that it is more possible for creative linguistic metaphors to be translated into conventionalized expressions having the same conceptual metaphors. Of course, it requires much more research on the question under investigation and other similar ones related to this area to find out exactly why and to what extent it can happen. To suggest a few examples, further research could be carried out on the novels Nineteen Eighty-Four by George Orwell and Great Expectations by Charles Dickens along with their Persian translations. Conventional metaphors can also be changed into novel ones in translation, but it happens even more rarely. The reason is the certain degree of universality in terms of the predominant conceptual metaphors between the two languages. It seems even more unusual, considering the fact that most conventional metaphors are universal or at least near universal (Kovecses, 2005), to argue that it is possible for a translator to draw upon novel metaphors in the translation of conventional ones. Based on our findings, there are some reasons for this happening. Sometimes, the close equivalent available in a language for a certain conventional metaphor is a nonmetaphorical expression. The translator, in such a case, can either choose that non-metaphorical but quite conventionalized equivalent, or construct the same source domain by translating the metaphor literally, which will lead to a novel metaphorical expression-the one which is not conventionalized among ordinary speakers of the target language (we are in the same boat, see above). To make the matter more complicated, it is also possible-to a very low degree, though, that a translator, based upon the context in which that conventional metaphor occurs, will come up with an equivalent which is totally novel. Only one example has been found in our data in this regard, but the chances are that the metaphorical context of a literary work can support such a creative choice of metaphor in translation. If the megametaphors used in that context are novel, then creative translations of 
one or two conventional metaphors in the same limited context will not wildly damage the writer's style (the common flow, see above). Finally, the present study attempts to investigate the scale of conventionality in metaphor translation, to show how conventional and novel metaphors are translated: whether they remain conventional or novel or undergo some changes in the process of translation. This study is different from the previously done research in that it includes not only the opposite ends of this scale, i.e., entrenched and creative, but also the middle positions: the metaphors which are relatively novel. Furthermore, this study allows for the possibility that some metaphors are either conceptually or linguistically novel. To suggest further directions, Charles Dicken's novels and their translations to different languages can provide a good ground for metaphor analysis. The scale of metaphor conventionality in translation needs to be studied in other instances of prose fiction since this aspect of metaphor research has not been treated with due attention. It is hoped that such studies can be the focus of attention by cognitive stylistics and cognitive poetics researchers.

\section{REFERENCES}

Ashuja'a, A. A., Almatari, S. M., \& Alward, A. S. (2019). Exploring Strategies of Translating Metaphor from English into Arabic with Reference to Scientific Texts. International Journal of Comparative Literature and Translation Studies, 7(3), 26-38.

Al-Hasnawi, A.R. (2007). A cognitive approach to translating metaphors. Translation Journal, 11(3). 43-59.

Burmakova, E. A., \& Marugina, N. I. (2014). Cognitive approach to metaphor translation in literary discourse. Procedia- Social and Behavioral Sciences, 154, 527-533. Doi: 10.1016/ j. sbspro.2014.10.180.

Cristofoli, M., Dyrberg, G., Stage, L. (1998). Metaphor, meaning and translation. Hermes - Journal of Language and Communication in Business, 20: 165-179.

Dickins, J. (2005). Two models for metaphor translation. Target, 17.2: 217273.

Dobrynska, T. (1995). Translating metaphors: Problems of meaning. Journal of Pragmatics, 24(6), 595-604.

Dobrovol'skij, D., Piirainen, E. (2005). Figurative language: Cross-cultural and cross-linguistic perspectives. Brill.

Fernández, E. S. (2013). The impact of cognitive linguistics on descriptive translation studies: Novel metaphors in English-Spanish newspaper 
translation as a case in point. In Cognitive linguistics and translation (pp. 159-198). De Gruyter Mouton.

Golfam, A., Ghorbanpour A., and Mahdipour N., (2019). A comparative study of the conceptual metaphors of time in Persian and English. Journal of Applied Studies in Language, 3(1), 43-55. Doi:10.31940/ jasl. v3i1.1342.

Indurkhya, B. (1992). Metaphor and cognition: Studies in cognitive systems. Dordrecht: Kluwer Academic Publishers.

Kovecses, Z. (2003). Metaphor and emotion: Language, culture, and body in human feeling. Cambridge: Cambridge University Press.

Kovecses, Z. (2005). Metaphor in culture: Universality and variations. Cambridge: Cambridge University Press.

Kovecses, Z. (2010). Metaphor: A practical introduction. New York: Oxford University Press.

Kövecses, Z. (2018). Metaphor universals in literature. ANTARES: Letras e Humanidades, 10(20), 154-168.

Lakoff, G., \& Johnson, M. (1980/ 2003). Metaphors we live by. Chicago \& London: University of Chicago Press.

Lakoff, G., \& Turner, M (1989). More than cool reason. Chicago: University of Chicago Press.

Lakoff, G. (1999). Philosophy in the flesh: The embodied mind and its challenge to Western thought. New York: Basic Book.

Le Guern, M. (1976). La metáfora y la metonimia, trad. Augusto de Gálvez Cañero y Pidal (Madrid, Cátedra, 1976).

Maalej, Z. (2008). Translating metaphor between unrelated cultures: A cognitive-pragmatic perspective. Sayyab Translation Journal (STJ), 1: 60-82.

Mandelblit, N. (1995). The cognitive view of metaphor and its implications for translation theory. Translation and meaning, Part 3 (pp. 482-495).

Muller, C. (2008). Metaphors dead and alive, sleeping and waking: A dynamic view. Chicago: University of Chicago Press.

Munday, J. (2001). Introducing translation studies: Theories and applications. Abingdon/ New York: Routledge. 
Musolff, A. (2021). Cultural conceptualizations of the nation as a body or person: Scenario analysis of metaphor interpretations. In: National Conceptualizations of the Body Politic. Cultural Linguistics. Singapore: Springer.

Nacey, S. (2013). Metaphors in learner English. Amsterdam: John Benjamins Publishing Company.

Newmark, P. (1988). A textbook of translation (Vol. 66). New York: Prentice hall.

Omar, L., I. (2012). A Cognitive approach to the translation of creative metaphor in Othello and Macbeth from English into Arabic. (Doctoral dissertation, Durham University).

Group, P. (2007). MIP: A method for identifying metaphorically used words in discourse. Metaphor and symbol, 22(1), 1-39.

Rabadán, R. (1991). Equivalencia y traducción. Problemática de la equivalencia translémica inglés-español. León, Spain: Universidad de León.

Rojo, A., \& Ibarretxe- Antuñano, I. (Eds.). (2013). Cognitive linguistics and translation: Advances in some theoretical models and applications. Berlin/ Boston: de Gruyter.

Safarnejad, F., Ho- Abdullah, I., \& Awal, N. M. (2014). Cultural basis of conceptual metaphors translation: Case of emotions in Persian and English. Asian Social Science, 10(7), 107-118.

Said Ghazala, H. (2012). Translating the metaphor: A cognitive stylistic conceptualization. World Journal of English Language, 2, 57-68.

Schäffner, C. (2004). Metaphor and translation: Some implications of a cognitive approach. Journal of Pragmatics, 36.7: 1253-1269.

Schäffner, C., \& Shuttleworth, M. (2013). Metaphor in translation: Possibilities for process research. Target, 25(1), 93- 106.

Schäffner, C., \& Chilton, P. (2020). Translation, metaphor and cognition. In The Routledge Handbook of Translation and Cognition (pp. 326-343). Routledge.

Schwieter, J. W., \& Ferreira, A. (Eds.). (2017). The handbook of translation and cognition. Hoboken: Wiley Blackwell.

Shakespeare, W. (1623). The first folio: Comedies, histories, \& tragedies. London. Printed by Isaac Jaggard, and Ed. Blount. 
Shuttleworth, M., \& Cowie, M. (1997). Dictionary of translation studies. Manchester: St. Jerome Publishing, 192, 193.

Shuttleworth, M. (2011). Translational behaviour at the frontiers of scientific knowledge: A multilingual investigation into popular science metaphor in translation. The Translator, 17(2), 301-323.

Shuttleworth, M. (2017). Studying scientific metaphor in translation: An inquiry into cross-lingual translation practices. Routledge.

Simpson, P. (2004). Stylistics: A resource book for students. London and New York: Routledge.

Steen, G. (1994). Understanding metaphor in literature: An empirical approach. Longman Publishing Group.

Steen, G. (2017). Identifying metaphors in language. In Semino, E., \& Demjén, Z. (Eds.), The Routledge handbook of metaphor and language (pp. 73-87). Abingdon: Routledge.

Toltz, S. (2008). A fraction of the whole. Australia: Hamish Hamilton.

Henry David Thoreau. (1985). A week on the Concord and Merrimack rivers. : Walden, or, Life in the Woods [u.a.]. Cambridge: Cambridge Univ. Pr.

Tirkkonen-Condit, S. (2001). Metaphors in translation processes and products. Quaderns. Revista de Traducció, 6: 11-15.

Toury, G. (1995). Descriptive translation studies and beyond. Amsterdam: John Benjamins.

Van den Broeck, R. (1981). The limits of translatability exemplified by metaphor translation. Poetics Today, 2.4: 73-87.

Wong, D. (2007). John dies at the end. New York: Permuted Press.

Yan, D., Noël, D., \& Wolf, H. G. (2010). Patterns in metaphor translation: a corpus-based case study of the translation of FEAR metaphors between English and Chinese. Using Corpora in Contrastive and Translation Studies. Newcastle: Cambridge Scholars Publishing, 4061. 